\title{
Seed, seedling, tirodendro morphology and germination of Anadenanthera macrocarpa (Benth.) Brenan (Fabaceae, Mimosoideae)
}

\author{
(D) Maria do Carmo Learth Cunha ${ }^{1,3}$, iD Tamires Leal de Lima ${ }^{1}$, (D) Thiago Costa Ferreira ${ }^{2}$, \\ Yathaanderson Mendes dos Santos ${ }^{1}$
}

Received: 02.06.2020; accepted: 14.08 .2020

How to cite: Cunha, M.C.L., Lima, T.L., Ferreira, T.C., \& Santos, Y.M. 2020. Seed, seedling, tirodendro morphology and germination of Anadenanthera macrocarpa (Benth.) Brenan (Fabaceae, Mimosoideae). Hoehnea 47: e592020. http://dx.doi.org/10.1590/2236-8906-59/2020

ABSTRACT - (Seed, seedling, tirodendro morphology and germination of Anadenanthera macrocarpa (Benth.) Brenan (Fabaceae, Mimosoideae)). The specie Anadenanthera macrocarpa (Benth.) Brenan, angico-vermelho, is little studied regarding the morphological characters of its seeds, seedlings and tirodendo. Therefore, the aims of this study were to describe and illustrate the morphology of seed germination, seedling and tirodendro of angico-vermelho. Seeds of five matrices were harvested and submitted to germination test at $28{ }^{\circ} \mathrm{C}$ on paper roll and vermiculite substrates. The seeds are euryspermics with horseshoe-shaped pleurograma and seedlings epigeal-phanerocotylar. The seedling eophylls are compound, bi-pinnate, opposite, oblong-shape laminar and based asymmetric. Petiole has reddish oval gland at the beginning, and two to three rounded glands between the last pinnae. Eophylls and metaphylls have similar morphological characteristics, except for the pinnae number. The tirodendro presents metaphylls compounds bi-pinnate opposite, with gradual hypertrophy of the taproot 27 th day after sowing, the xylopodium, that becames larger until 180 days.

Keywords: angico, biometry, botany, dry forest, xylopodium

RESUMO - (Sementes, plântulas, morfologia do tirodendro e germinação de Anadenanthera macrocarpa (Benth.) Brenan (Fabaceae,Mimosoideae)). A espécie Anadenanthera macrocarpa (Benth.) Brenan, angico-vermelho, é pouco estudada quanto aos caracteres morfológicos de suas sementes, mudas e tirodendo. Portanto, os objetivos deste estudo foram descrever e ilustrar a morfologia da germinação de sementes, plântulas e tirodendros de angico-vermelho. Sementes de cinco matrizes foram colhidas e submetidas ao teste de germinação a $28^{\circ} \mathrm{C}$ em rolo de papel e substratos de vermiculita. As sementes são euripermicas com pleurograma em forma de ferradura e mudas epigeal-fanerocotilares. Os eofilos das mudas são compostos, bi-pinados, opostos, laminados de forma oblonga e baseados assimétricos. O pecíolo possui glândula oval avermelhada no início e duas a três glândulas arredondadas entre as últimas pinças. Eofilos e metafilos têm características morfológicas semelhantes, exceto pelo número de pinos. O tirodendro apresenta compostos metafílicos bipinados opostos, com hipertrofia gradual da raiz principal 27 dias após a semeadura, o xilopódio, que aumenta até 180 dias.

Palavras-chave: angico, biometria, botânica, floresta seca, xilopódio$$
\text { (1) }
$$

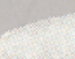

the greatest geographical coverage in Brazil (Carvalho 2003). It is a deciduous pioneer specie, which occurs most commonly in well-drained land with flowering from August to September and fruiting from September to October, with annual seed

1. Universidade Federal de Campina Grande, Avenida Universitária, s/n, Santa Cecilia, 58708-110 Patos, PB, Brasil

2. Instituto Nacional do Semiárido, Avenida Francisco Lopes de Almeida, s/n, Serrotão, 58434-700 Campina Grande, PB, Brasil

3. Corresponding Author: c.learth@uol.com.br 
production. Its fruits are legumes flattened surface rough and brown color (Lorenzi 2008) with one slit dehiscence. The specie has economic importance in the Brazilian semiarid region (Silva \& Barbosa 2000) with uses for extraction of tannin, in folk medicine (Monteiro et al. 2006), furniture manufacturing (Born 2007), fodder (Drummond et al. 2004), ornamentation and coal, among others (Rodrigues et al. 2007). It occurs with high frequency and dominance in preserved areas in the Southeast of Brazil (Marinelli 2006) and Caatinga exploited (Silva \& Barbosa 2000).

Plants species identification could be accomplished by botanical, anatomical or dendrological studies, each using separate characters. In systematic botany, species identification is performed using characters found in individual's adults, while seedlings characteristics are less used, maybe by limiting studies (Donadio \& Demattê 2000). The morphological features of seeds (Barroso 1978), fruits and seedlings (Kuniyoshi 1983, Ramos \& Ferraz, 2008) allowsfamily, genera and species identification. They are important for researches in plant biology, ecology, phylogeny investigations, forestry, recovery of degraded areas, colonization of new environments by native or exotic species and research of medicinal and toxic plants (Souza 2009), besides studies on standar disation laboratory germination tests (Silva et al. 1995), research on soil seed bank and natural regeneration (Araújo Neto et al. 2002). All of them helps the understanding of plant populations and community's dynamics and the forest successional stage (Oliveira 1993, Donadio \& Demattê 2000).

The morphological classification of seedlings began with Duke's studies (1965), supplemented by Ng (1978), Vogel (1980), Duke \& Polhill (1981), Miquel (1987), Garwood (1983), Garwood (1996) and Ibarra-Manríquez et al. (2001). These authors considered aspects such as the position and exposure of cotyledons, seed morphology and phyllotaxis of eophylls, persistence or not of seed coat, the amount of reserves stored after seedling establishment and time of reserves persistence in seedlings. In Brazil, the morphological description of seeds and seedlings has been studied in several species (Abreu et al. 2005, Guerra et al. 2006, Cosmo et al. 2009, Rego et al. 2010), with morphofunctional (Ressel et al. 2004) and anatomical and morphological approaches (Cosmo et al. 2009, Souza 2009).

Plant differences, as well as the external and internal aspects that might have in common, are susceptible to large-scale evaluation by morphological characters, that are expressed in fruits, seeds, and seedlings and are reliable according to their constancy (Lawrence 1973) and sufferless changes on different environments (Gunn 1981). Seedlings can provide numerous characters for species identification (Oliveira 2001), as well as information that is vital in early seedling establishment, as types of germination, morphology and eophyllsarrangement, presence or absence of indument on hypocotyl or cotyledons, presence of chlorophyll in the embryo and seed size (Garwood 1996).
Studies have shown that plants in seedling stage may have different characters according to the life stage (Ferreira $\&$ Cunha 2000, Silva et al. 2008) and require taxonomic and ecological studies in initial growth (Davide \& Keys 1996, Silva et al. 2008). The Fabaceae family comprises about 650 genera and 18,000 species (Gunn 1984) and some with taxonomic and phylogenetic problems whose fruits and seeds analysis could solve them. The family has been prominent in studies of morphological description (Lopes \& Matheus 2008, Nogueira et al. 2010, Alves 2011) and studies on morphological variations of fruits, seeds and seedlings in Fabaceae-Mimosoideae have been used to supplement and characterize some taxa (Barroso et al. 1999, Araújo Neto et al. 2002, Melo \& Varela, 2006; Ramos \& Ferraz 2008, Barreto \& Ferreira 2011).

Considering the above, the aims of this study were to describe and illustrate the morphology of seed germination, seedling and tirodendro of angico-vermelho, Anadenanthera macrocarpa.

\section{Materials and methods}

Seeds harvest and experiments - Mature fruits were hand harvested from five-selected tress, at least $100 \mathrm{~m}$ apart, in Patos and São José de Espinharas cities, Paraíba State, brazilian Northeastern, and placed under shade to complete the drying process to allow easy seed extraction after naturally opening fruits. All malformed and bruised seeds were rejected. Matrices were select considering plant health and fruiting intensity. The study was carry in Forestry Seed Laboratory of Federal University of Campina Grande (UFCG), the Campus of Patos, Paraiba State, Brazil.

Moisture content determination and germination test Seed moisture content test was determined by drying them at $105 \pm 3{ }^{\circ} \mathrm{C}$ for 24 hours, with three replicates of 3 grams for each matrix. The number of viable seeds per kilogram and thousand seed weight was determined according to the recommendations of the Rules for Testing Seeds (Brasil 2009 a). The germination test was carried out on $28{ }^{\circ} \mathrm{C}$ constant temperature in a germination chamber and 12 hours photoperiod, for each matrix. Two sterilized substrate were used: paper roll and vermiculite. Paper was sterilized in a stove at $90^{\circ} \mathrm{C}$ for 24 hours and vermiculite at $150^{\circ} \mathrm{C}$ for the same period. The vermiculite was placed in boxes $31.00 \times 23.00 \times 4.00 \mathrm{~cm}$ dimensions and moistened with distilled water to field capacity and the paper 2.5 times the weight of it.

Seeds were disinfected in $5 \%$ sodium hypochloride $(\mathrm{HClO})$ solution for 10 minutes and then washed four times with distilled water. Evaluations of germination were performed daily and were considered germinated seeds showing radicle protrusion (Pine et al. 2010). The experimental design was completely randomized, with four replications of 50 seeds.

Morphological description of seed, germination, seedling and tirodendro - Twenty seeds of each matrix were taken to 
perform external and internal seed morphology descriptions. The former described dimensions (length, width, and thickness) obtained with Vernier caliper, color, texture, integument consistency, shape, hilum position, micropyle and pleurograma shape. Seed internal characteristics were cotyledons shape, embryonic axis size and position and endosperm presence or not. To monitoring and describe germination and seedling development three stages were taken. The first, called germination phase, considered from seed swelling until cotyledons emergency, without eophylls expansion. The second, seedling phase was considered from the eophyll emergence until metaphyll emergency, and the third one, the tirodendro (Souza 2009), characterized by the metaphyll emergence (Brasil 2009b) to $20 \mathrm{~cm}$ height. These three morphological phases description phases were performed from 50 seedlings of each matrix.

Nursery stage - After radicle protusion in germinator, seeds were tilled in polyethylene bags $(11.00 \times 23.00 \times$ $6.00 \mathrm{~cm}$ ) receiving the substrate mixture of subsoil: cattle manure (1:1, by volume), and kept under shading screen (artificial shade 50\%) for 30 days and after that under full sun. The vegetative elements observed and described in this phase was: a) germination type; b) root shape, color, and root hairs; c) hypocotyl and epicotyl shape, color, surface, elements like cataphyll, hairs, lenticels striate presence; d) cotyledons position, petiole, insertion, shape, color, venation; e) eophylls and metaphyll or phyllotaxy, petiole, blade shape, margin, color, venation, stipules, hairs and presence of elements like thorns or glands (Souza 2009). These three morphological phases parameters observations were helped by binocular microscope and enlarged for better viewing with the actual measurements expressed.

\section{Results and Discussion}

The seeds are eurispermics, lenticular with smooth and shiny surface. Seed coat color ranges from dark brown to brown with hard consistency; edges with slight indentations; pleurograma horseshoe-shaped with open arms wide apart on both sides and in the middle of the seed (figure 1). Pleurograma takes place only in Fabaceae-Mimosoideae family in some species of Caesalpinoideae and Curcubitaceae (Beltrati 1990) and assists species identification through seeds. Micropyle has apical position and hilo is small, homochromus, that is, same testa's colour, and oval shape (figure 1). Embryo is axial, straight and endosperm lacking. Cotyledons are fleshy (Vogel, 1980), with no pleurograma impression (or sign), cream-colored, bright, and gives the seed form. The embryo-axis is cylindrical, with well develop plumule with differentiate pinnaeand epicotyl axis with internodes not extended (figures $1 \mathrm{e}, \mathrm{f}$ ).

The matrices seeds maximum and minimum dimensions are showed on Table 1.

Seeds kilogram number (9145 units) and thousand seed weight $(109,35 \mathrm{~g})$ was similar to those found by Moreau (2011). Variations on seeds size and color were accompanied by differences in moisture content and germination between

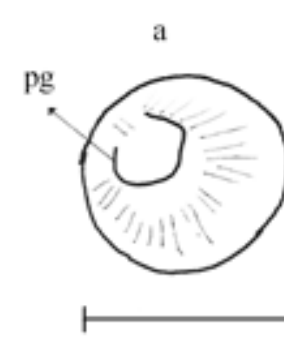

1,3

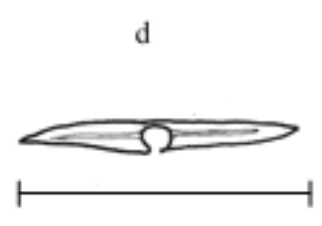

1.5

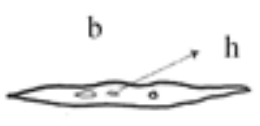

$\mathrm{e}$

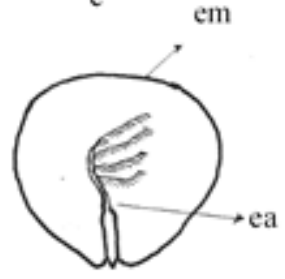

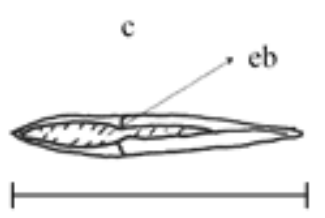

1.3

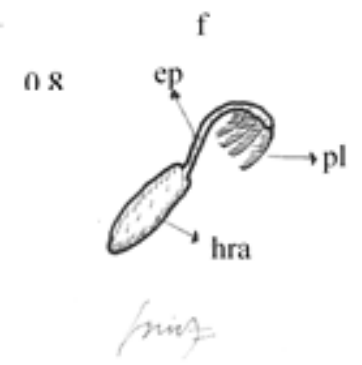

Figure 1. Outer and inner morfology of Anadenanthera macrocarpa (Benth.) Brenan seeds. a. Seed in lateral view. b. micropyle. c. longitudinal section. d. cross-section. e. embryo-axis position. f. embryo-axis details. pg. pleurograma. h. hilum. ea. embryonic-axis. em. embryo. ep. epicotyl. pl. plumule. hra. hypocotyl-radicle axis. 
Table 1. Seeds dimensions (length, width and thickness) of five matrices of Anadenanthera macrocarpa (Benth.) Brenan

\begin{tabular}{lcccc}
\hline Matrix & Length $(\mathrm{mm})$ & Width $(\mathrm{mm})$ & Thickness $(\mathrm{mm})$ & Embryo-axis $(\mathrm{cm})$ \\
\hline 1 & $10.0-12.0$ & $9.4-13.4$ & $0.75-1.25$ & $0.5-0.8$ \\
2 & $10.1-12.7$ & $9.1-12.1$ & $1.00-1.35$ & $0.5-0.7$ \\
3 & $10.3-13.0$ & $10.0-13.0$ & $0.80-1.35$ & $0.6-0.7$ \\
4 & $10.0-13.0$ & $9.8-12.6$ & $1.00-1.35$ & $0.4-0.6$ \\
5 & $12.9-14.8$ & $9.6-13.8$ & $1.20-1.90$ & $0.7-0.9$ \\
\hline
\end{tabular}

Table 2. Moisture content (U\%), germination percentage ( $\mathrm{G} \%$ ) of five matrices seeds on vermiculite and paper roll substrates and thousand seed weight (g), number of seeds per kilogram of Anadenanthera macrocarpa (Benth.) Brenan.

\begin{tabular}{lccc}
\hline \multirow{2}{*}{ Matrix } & Moisture content (U\%) & \multicolumn{2}{c}{ Germination (\%) } \\
\cline { 3 - 4 } & 11 & Paperroll & Vermiculite \\
\hline 1 & 9.44 & 54.5 & 11 \\
2 & 10.74 & 18.5 & - \\
3 & 10.63 & - & 20 \\
4 & 6.81 & 36 & 82.5 \\
\hline & & 92 & 37.87 \\
\hline
\end{tabular}

matrices (Table 2), probably because of different maturation stages.

The matrix with lower moisture content had superior performance in germination, probably because of advanced physiological maturation stage, and shows environment and individual development influences on physiological maturation (Lopes et al. 2005). The seed harvest time can determine variations in germination, as seed quality tends to decline by deterioration (Oak \& Nakagawa 2000.). Seeds moisture content is important to physiological quality maintenance (Garcia et al. 2004). Calophyllum brasiliensis seeds showed the same behavior, that is, seed water content variations affected their germination (Nery et al. 2007).

Germination is epigeal-phanerocotylar (Moreau 2011), with inconspicuous hypocotil. This germination is common in Fabaceae-Mimosoideae family, as Anadenanthera colubrina (Vellozo) Brenan, Enterolobium contortisiliquum (Vellozo) Morong (Barreto \& Ferreira 2011), Dinizia excels Ducke, Cedrelinga catenaeformis Ducke (Melo \& Varela 2006) and Enterolobium schomburgkii Benth (Ramos \& Ferraz 2008) species. The primary white color and cilyndrical root emergency occurs by rupture of the integument at the micropylar side, about 24 hours after seeding. The hypocotyl-radicle axis and the cotyledons emerge through the tegument, that remains attached to the cotyledons for about three days (figure 2).

After detachment of the seed coat, occurs the full opening of the cotyledons, opposite and obliquely inserted, that are photosynthesizing. They have orbicular form and no hairs, that is glabrous, and at this stage with lime-green color, without apparent venation or punctuations. The cotyledon petiole is short with the presence of stipules interpetiolar. The base of the cotyledon is sagittate and rounded apex, with entire margin and crassa consistency. The eophyll is composite, opposite bipinnate, oblong-shape, based asymmetric, apex acute to mucronate, margin entire; pubescence on the adaxial and abaxial face and simple margin. Eophyll's petiole is cylindrical with two filiforme and yellow intrapetiolar stipules, with simple hairs. The epicotyl is cylindrical, reddish near the cotyledons and green in the eophyll, pilose, with simple hairs. The presence of filiform lenticels evenly distributed was noticed. Hypocotyl is yellow, cylindrical, pilose, with simple curved hairs and vertical grooves (figure 3 ). The primary root has white coloring, is thin, cylindrical, with early secondary branches. The scar left by the cotyledons remains visible up to this stage.

Eophyll and metaphylls present similar morphological characteristics, except for the pinnae number, which tends to grow. In this case they do not have the sequence of simple to compounds, gradual or abrupt, described by Duke (1969). Metaphylls are composed, opposing bipinnate; slightly discolored, with simple hairs on the surface of leaflet's limbo. Petiole grooved on the adaxial surface with filiform stipules interpetiolar with simple hairs coloring dark brown as axillary bud with dark brown pubescence (figure 4).

The extreme measures of the petiole, number of leaflets and leaflets are in Table 3. It can be observed that in relation to the petiole, leaflets and pinnules there is a constancy and similarity between as matrices. However, matrix 3 does 


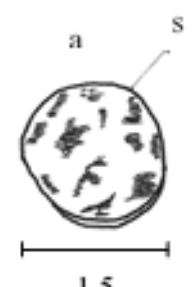

1.5
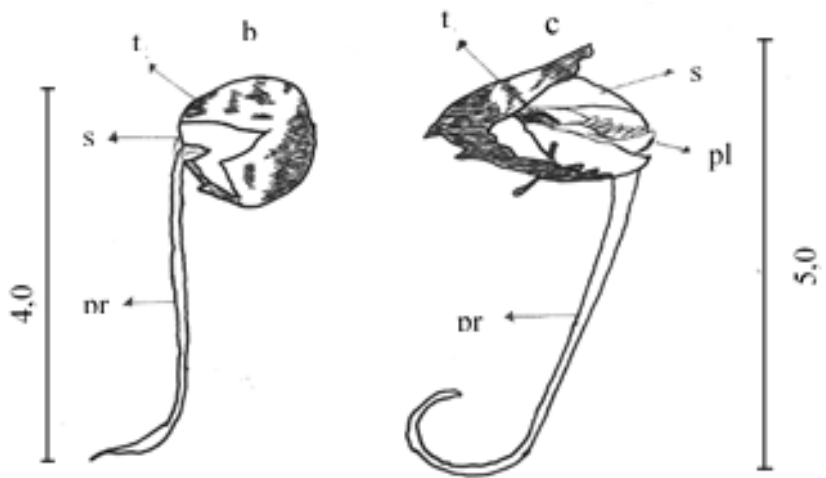

d
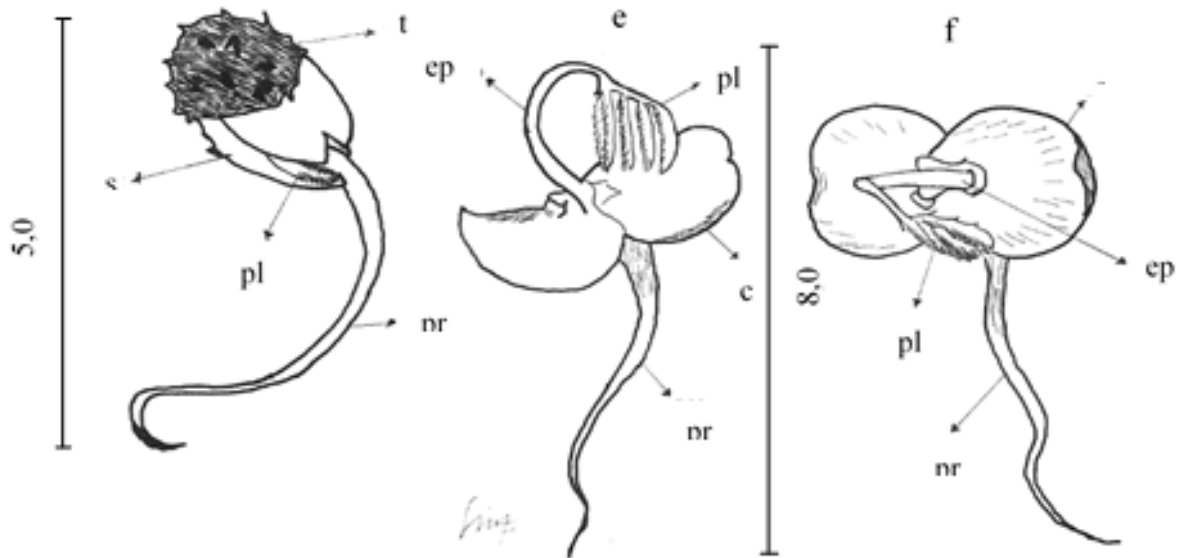

Figure 2. Germination morphology of Anadenanthera macrocarpa (Benth.) Brenan. a. swollen seed. b. radicle protrusion. c and d. radicle-hypocotyl axis growth and release of the integument. e. and f. eophyll's emergency. s. seed. pr. primary root. t. integument. s. cotyledons. pl. plumule. ep. Epicotyl.

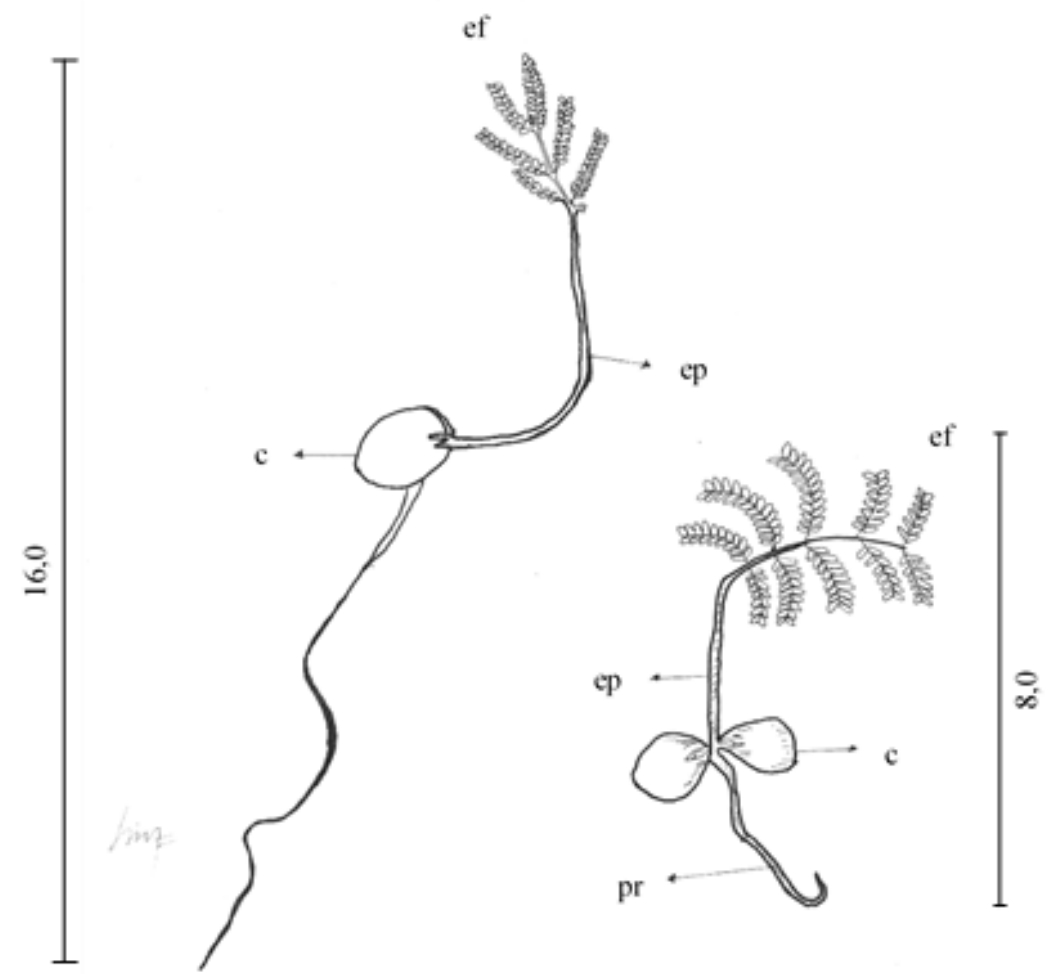

Figure 3. Morphological characterization of stage of Anadenanthera macrocarpa (Benth.) Brenan seedlings. ef. eophyll. ep. epicotyl. c. cotyledons. pr. primary root. 
Table 3. Extreme measures of petiole, number of leaflets and leaflets of Anadenanthera macrocarpa (Benth.) Brenan tirodendro.

\begin{tabular}{|c|c|c|c|c|}
\hline \multirow{2}{*}{ Matrix } & \multirow{2}{*}{ Petiole $(\mathrm{cm})$} & \multicolumn{2}{|c|}{ Leaflets (units) } & \multirow{2}{*}{$\begin{array}{c}\text { Pinnule } \\
\text { (units) }\end{array}$} \\
\hline & & Eophyll & Metaphyll & \\
\hline 1 & $1.5-2.5$ & $6-10$ & $8-10$ & $36-48$ \\
\hline 2 & $1.0-2.0$ & $6-8$ & $8-10$ & $44-56$ \\
\hline 3 & - & - & - & - \\
\hline 4 & $1.0-2.5$ & $6-8$ & $8-12$ & $46-56$ \\
\hline 5 & $1.3-2.0$ & $6-8$ & $8-12$ & $44-48$ \\
\hline
\end{tabular}

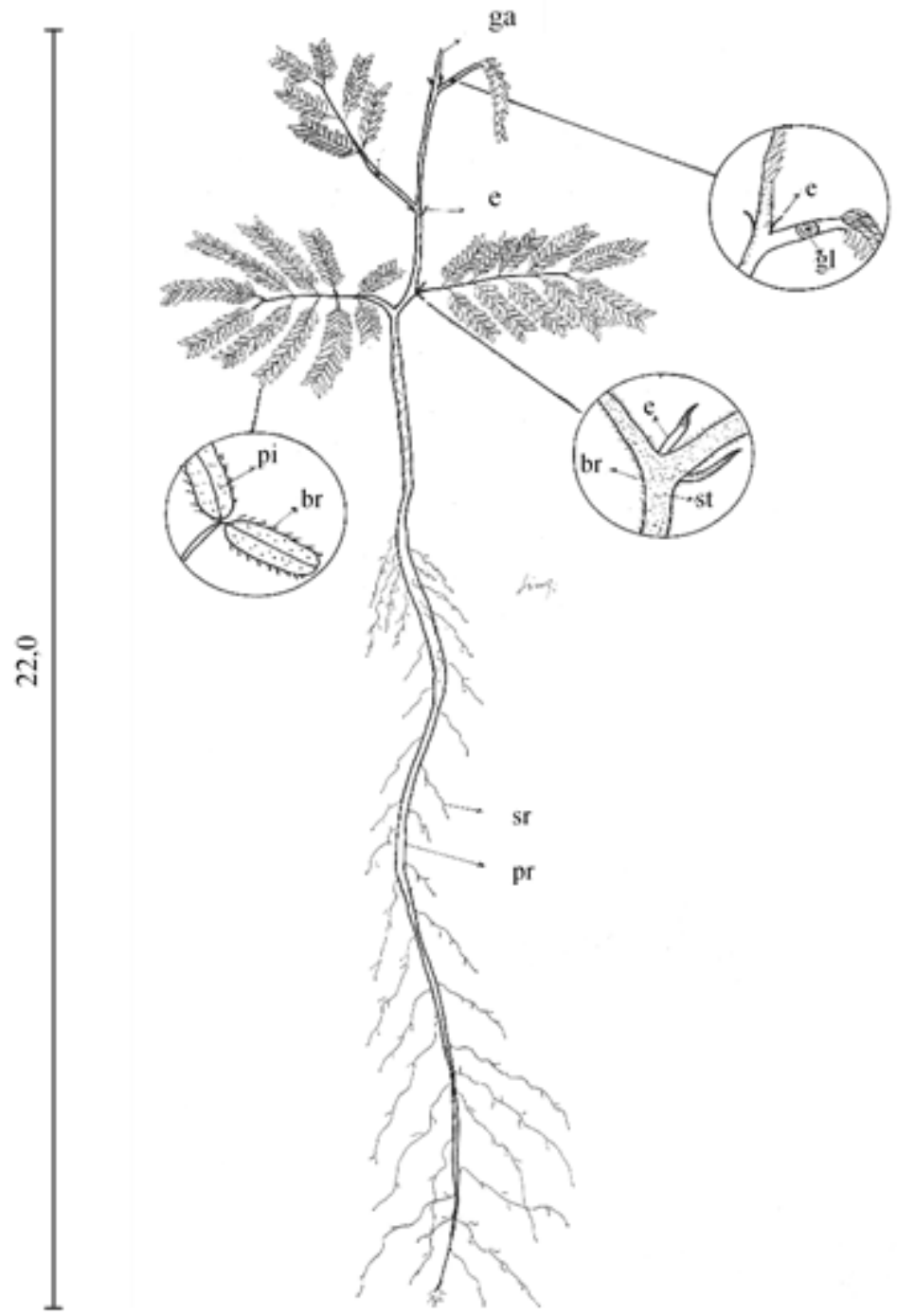

Figure 4. Morphological characterization of development stage of Anadenanthera macrocarpa (Benth.) tirodendro. ga. apical. gl. gland. e. stipule. pi. pinnule. br. bristle. st.stem. rp primary root. rs secondary root.

not have these characteristics, probably a genetic variable (Ferreira \& Cunha 2000, Silva et al. 2008).

The Stem is straight, cylindrical, base dark brown with filiforme lenticels green colour at the apex (figure 4). The scar left by the cotyledons is still visible. Taproot with streaks and early desquamation, without pubescence, with the root's secondary of the same length and color dark brown and slightly branched tertiary roots (figure 5). Twenty-seven days after 

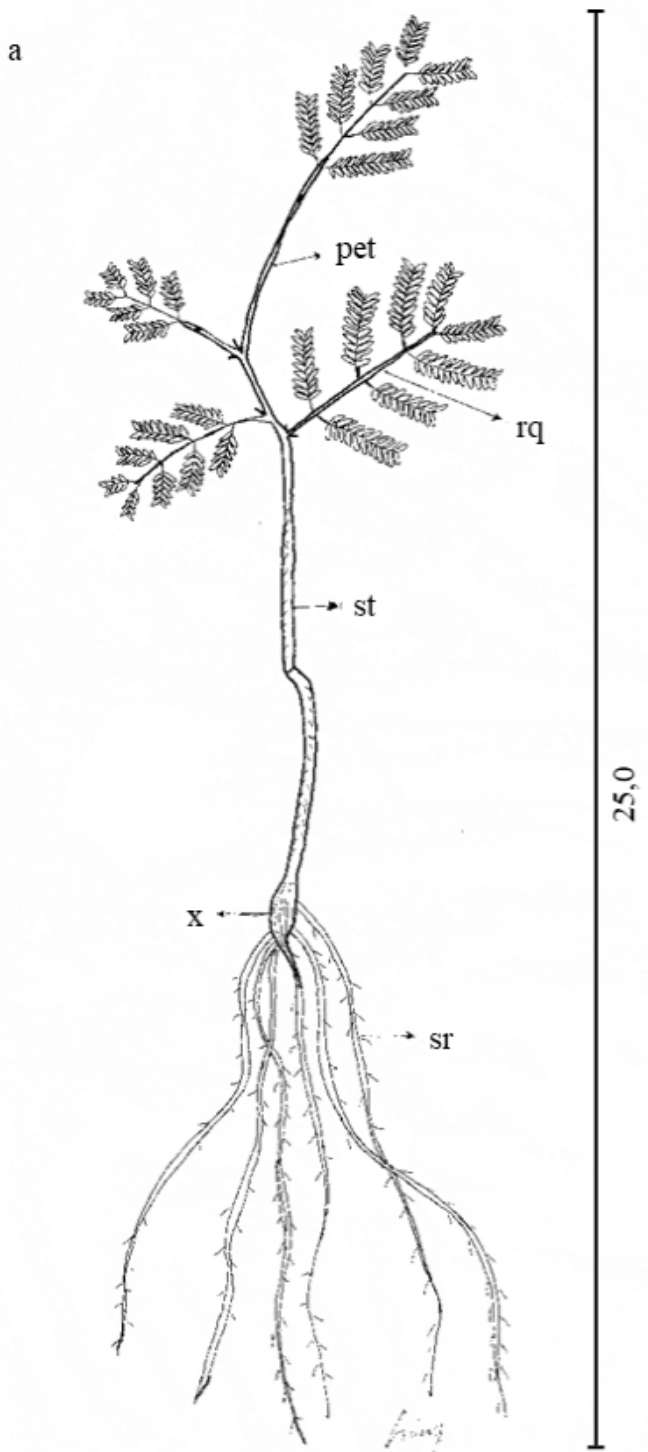

b

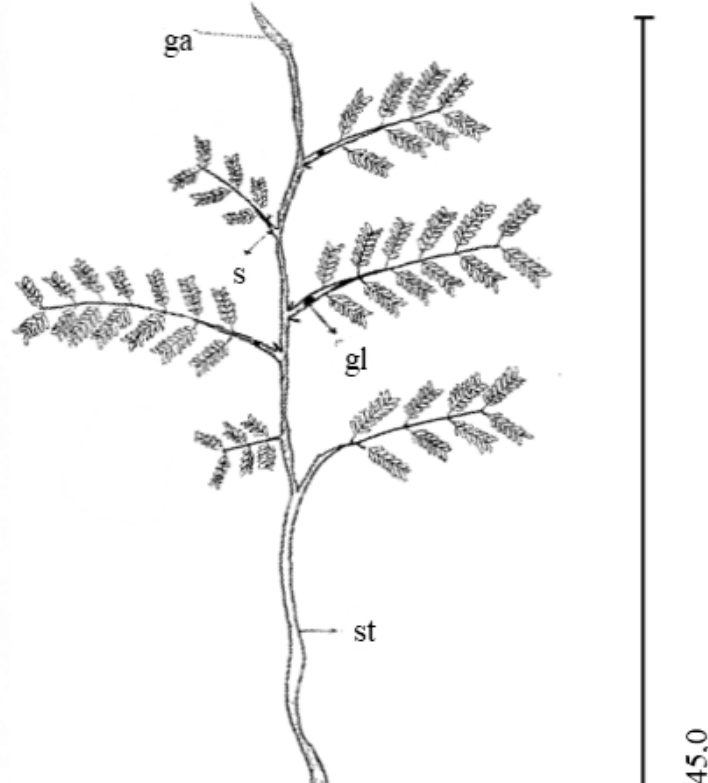

$\stackrel{\circ}{\wp}$

Figure 5. Morphological characterization of development stage of Anadenanthera macrocarpa (Benth.) Brenan tirodendro. a. initial formation of xylopodium. b. xylopodium formed. pet. petiole. rq. rachis. st. stem. x. xylopodium. rs. secondary root. ga. apical gem. s. stipule. gl. gland.

sowing, there was a gradual enlargement of the taproot, the xylopodium, as distinct in seedlings than six months (figure 5). The petiole has oval reddish gland in early stem, and two to three rounded glands between the last pinnae (figure 4).

\section{Conclusion}

The seeds are euryspermics with horseshoe-shaped pleurograma and seedlings epigeal-phanerocotylar. The seedling eophylls are compound, bi-pinnate, opposite, oblong-shape laminar and based asymmetric. Petiole has reddish oval gland at the beginning, and two to three rounded glands between the last pinnae. Eophylls and metaphylls have similar morphological characteristics, except for the pinnae number. The tirodendro presents metaphylls compounds bi-pinnate opposite, with gradual hypertrophy of the taproot 27th day after sowing, the xylopodium, that becames larger until 180 days.

\section{Acknowledgments}

This research was funded by $\mathrm{CNPq}$ (Conselho Nacional de Pesquisa), Process number 483774/2012-0, tytle of project: Genetic, Physiological and Sanitary quality of caatinga seeds and seedling trees. We grateful to CNPq and INSA, for employer this research. 


\section{Literature cited}

Abreu, D.C.A., Kuniyoshi, Y.S., Nogueira, A.C., Medeiros, A.C.S. 2005. Morphological characterization of fruits, seeds and germination of Allophylus edulis (St. Hi.) Radlk. (Sapindaceae). Journal of Seed Science 27:59-66.

Alves, M.C.J.L. 2001. Morfofuncionalidade de plântulas de espécies lenhosas de uma área de restinga. Dissertação de Mestrado), Universidade Federal Rural de Pernambuco, Recife.

Amaro, M.S., Filho, S.M., Guimarães, R.M., Teófilo, E.M. 2006. Morphology of fruits, seeds and seedling of Janaguba (Himatanthus drasticus (Mart.) Plumel. Apocynaceae. Journal of Seed Science 28:63-71.

Araújo Neto, J.C., Aguiar, I.B., Ferreira, V.M., Paula, R.C. 2002. Morphological characterization of fruits and seedlings and pos-semianl of monjoleiro (Acacia polyphylla DC.). Journal of Seed Science 24:203-211.

Barreto, S.S.B., Ferreira, R.A. 2011. Morphological aspects of fruits, seeds, seedlings from Leguminosae, Mimosoideae: Anadenanthera colubrina (Vellozo) Brenanand and Enterolobium contortisiliquum (Vellozo) Morong. Journal of Seed Science 33:223-232.

Barroso, G.M. 1978. Sistemática de Angiospermas do Brasil. Livros técnicos e científicos, Editora da USP.

Barroso, G.M., Morim, M.P., Peixoto, A. L., Ichaso, C. L. F. 1999. Frutos e sementes: morfologia aplicada à sistemática de dicotiledôneas. Viçosa: UFV.

Beltrati, C.M. Morfologia e anatomia de sementes. 1990. Rio Claro: Curso de pós-graduação em Ciências Biológicas. Instituto de Biociências.

Brasil. 2009 a. Regras para análise de sementes. Brasília: Mapa/ACS.

Brasil 2009 b. Glossário ilustrado de morfologia. Brasília: MAPA/DAS, 2009b.

Carvalho, N.M., Nakagawa, J. 2000. Sementes: ciência, tecnologia e produção. Jaboticabal: FUNEP. 4 ed.

Carvalho, P.E.R. 2003. Espécies arbóreas brasileiras. Colombo: Embrapa-CNPF, Brasilia, D.F.: Embrapa-SPI.

Cosmo, N.L., Gogosz, A.M., Nogueira, A.C., Bona, C., Kuniyoshi, Y.O. 2009. Morfologia do fruto, da semente e morfo-anatomia de plântulas de Vitexmage potamica (Spreng.) Moldenke (Lamiaceae). Acta Botânica Brasileira 23: 389-397.

Paes, J. B., Diniz, C. E. F., Marinho, I. V., Lima, C. R. 2003. Avaliação do potencial tanífero de seis espécies florestais de ocorrência no semi-árido brasileiro. In: Congresso Florestal Brasileiro VIII, 2003, São Paulo. Anais do... São Paulo: SBS/SBEF.

Donadio, N.M.M., Demattê, M.E.S.P. 2000. Morfologia de frutos, sementes, e plântulas de canafístula (Peltophorum dubium (Spreng.) Taub.) e jacarandá-da-Bahia (Dalbergia nigra (Vell.) Fr. All. exBenth.) -Fabaceae. Journal of Seed Science 22: 64-73.
Drumond, M.A., Santana, A.C., Antonioli, A. 2004. Recomendações para o uso sustentável da biodiversidade no bioma da Caatinga. In: Biodiversidade da Caatinga: áreas e ações prioritárias para a conservação. Brasília: MMA-UFPE, Brasília, DF. pp. 47-90.

Duke, J.A. 1965. Keys for the identificacion of seedlings of some preeminent wood species in eight forest types in Puerto Rico. Annals of the Missouri Botanical Garden, Columbus 52: 314-350.

Duke, J. A. 1969. On tropical tree seedlings. I. Seeds, seedlings, systems and systematics. Annals of the Missouri Botanical Garden 56: 125-161.

Duke, J.A., Polhill, R.M. 1981. Seedlings of Leguminosae. In: Polhill, R. M., Raven, P. H. Advances in legume systematics. Kew: Crow Copyright, pp. 941-949.

Ferreira, R.A., Cunha, M.C.L. 2000. Aspectos morfológicos de sementes, plântulas e desenvolvimento da muda de Craibeira (Tabebuia caraiba Mart. Bur.) - Bignoniaceae e Pereiro (Aspidosperma pyrifolium Mart.). Apocynaceae. Journal of Seed Science 22:134143.xxx

Garcia, D.C., Barros, A.C.S.A., Peske,S.T., Menezes, N.L.A. 2004. secagem de sementes. Ciência Rural2: 603-608.

Garwood, N.C. 1983. Seed germination n a seasonal tropical forest in Parana: a community study. Ecological monographs 53: 159-181.

Garwood, N.C. 1996. Functional morphology of tropical tree seedlings. In: SWAINE, M. D. The ecology os tropical forest tree seedlings, Man \& Biosphere Series - UNESCO 17: 59-119.

Guerra, M.T.C., Filho, S.M., Gallão, M.I. 2006. Morfologia de sementes, de plântulas e da germinação de Copaifera langsdorfii Desf. (Leguminosae-Caesalpinoideae). Cerne 12: 322-328.

Gunn, C.R. 1981. Seed topography in the Fabaceae. Seed Science and Technology 9: 737-757.

Gunn, C.R. 1984. Fruits and seeds of genera in the subfamily Mimosoideae (Fabaceae). Boletim técnico $\mathrm{n}^{\circ}$ 1681. Agricultural Research Service. United States Departament of Agriculture, Washington DC.

Ibarra-Manríquez, G., Martinez-Ramos, M., Oyama, K. 2001. Seedling fuctional types in lowland rain forest in México. American Journal of Botany 88: 1801-1812.

Kuniyoshi, Y.S. 1983. Morfologia da semente e da germinação de 25 espécies arbóreas de uma floresta de araucária. Universidade Federal do Paraná. Curitiba.

Lawrence, G.H.M. 1973. Taxonomia das plantas vasculares. Lisboa: Fundação Caluste Gulbekian,

Lopes, J.C., Dias, P.C., Pereira, M.D. 2005. Maturação fisiológica de sementes de quaresmeira. Pesquisa Agropecuária Brasileira 40: 811-816. 
Lopes, J.C., Matheus, M.T. 2008. Caracterização morfológica de sementes, plântulas e da germinação de Dimorphandra wilsoniiRizz. - faveiro-de-Wilson (Fabaceae-Caesalpinioideae). Journal of Seed Science 30: 96-101.

Lorenzi, H. 2008. Árvores Brasileiras: Manual de identificação e cultivo de plantas arbóreas do Brasil. 4. ed. Nova Odessa: Instituto Plantarum.

Marinelli, P.C.S. 2006. Fitossociologia, deposição e decomposição de serrapilheira de reflorestamentos em área de encosta, do parque estadual do Grajaú - RJ.. Trabalho de Conclusão de Curso, Universidade Federal do Rio de Janeiro, Rio de Janeiro.

Melo, M.D.F.F., Varela, V.P. 2006. Aspectos morfológicos de frutos, sementes, germinação e plântulas de duas espécies florestais da Amazônia. I. Dinizia excelsa Ducke. (Angelim - pedra). II. Cedrelinga catenaeformis Ducke. (Cedrorana) - (Fabaceae-Mimosoideae). Journal of Seed Science 28: 54-62.

Miquel, S. 1987. Morfologiefonctionnelle de plantules d'especes forestiêresduGabon. Bull. Mus. Natn. Hist. Nat. Paris. Adansônia 9: 101-121.

Monteiro, J.M., Albuquerque, U.P., Lins Neto, E. M. et al. 2006. Use patterns and knowledge of medicinal species among two rural communities in Brazil's semi-arid northeastern region. J Ethnopharmacol 105: 173-186.

Moreau, J.S. 2011. Germinação de sementes em diferentes substratos e caracterização morfológica de plântulas de Anadenanthera macrocarpa (Benth.) Brenan. Trabalho de Conclusão de Curso, Universidade Federal do Espírito Santo, Jerônimo Monteiro.

Nascimento, M.F. 2007. CPH: Chapas de partículas homogêneas - Madeiras do nordeste do Brasil.153 f. Tese de Doutorado, Universidade de São Paulo, São Carlos.

Nery, F.C., Alvarenga, A.A., Santos, F.M., Nery, M.C., Pereira, V.B. Haro, M.M. 2007. Efeito do grau de umidade na qualidade de sementes de Calophyllum brasiliense Cambess - (Clusiaceae). In: Congresso de Ecologia do Brasil, 8., Caxambu. Anais do... Caxambu. 1 CD-ROM.

Ng, F.S.P. 1978. Strategies of establishment in Malayan forest trees. In: TOMLINSON, P. B., Zimmermann, M.H. Tropical trees as living systems. University Press, Cambridge, 129-162.

Nogueira, F.C.B., Medeiros Filho, S., Gallão, M.I. 2010. Caracterização da germinação e morfologia de frutos, sementes e plântulas de Dalbergia cearensis Ducke (pau-violeta) - Fabaceae. Acta Botanica Brasilica 24: 978-985.
Oliveira, D.M.T. 2001. Morfologia comparada de plântulas e plantas jovens de leguminosas arbóreas nativas: espécies de Phaseoleae, Sophoreae, Swartzieaee Tephrosieae. Brasilian Journal of Bothanic 24: 85-97.

Oliveira, E.C. 1993. Morfologia de plântulas. In: Aguiar, I. B., Piña Rodrigues, F. C. M., Figliolia, M. B. Sementes florestais tropicais. Brasília: ABRATES, pp. 175-214.

Pinho, D.S., Borges, E.E.L., Pontes, C.A. 2010. Avaliação da viabilidade e vigor de sementes de Anadenanthera peregrina (L.) Speg. submetidas ao envelhecimento acelerado e ao osmocondicionamento. Revista Árvore 34: 425-434.

Ramos, M.B.P., Ferraz, I.D.K. 2008. Estudos morfológicos de frutos, sementes e plântulas de Enterolobium schomburgkii Benth. (Fabaceae). Brasilian Journal of Bothanic 1: 227-235.

Rego, S.S., Nogueira, A.C., Kuniyoshi, Y.S., Santos, A.F. 2010. Caracterização morfológica do fruto, da semente e do desenvolvimento da plântula de Blepharocalyx salicifolius (H.B.K.) Berg. e Myrcengenia gertii Landrum - Myrtaceae. Journal of seed science 32: 52-66.

Ressel, K., Guilherme, F.A.G., Schiavini, I., Oliviera, P.E. 2004. Ecologia morfofuncional de plântulas de espécies arbóreas da Estação Ecológica do Panga, Uberlândia, Minas Gerais. Brasilian Journal of Bothanic 27: 311-323.

Rodrigues, A.C.C., Osuna, J.T.A., Queiroz, S.R.O. D., Rios, A.P.S. 2007. Efeito do substrato e luminosidade na germinação de Anadenanthera colubrina (Fabaceae, Mimosoideae). Revista Árvore 31: 187-193.

Silva, K. B., et al. 2008. Morfologia de Frutos, Sementes, Plântulas e Plantas de Erythrina velutina Willd., Leguminoseae - Papilionideae. Journal of Seed Science 30: 104-114.

Silva, L.M.B., Barbosa, D.C.A. 2000. Crescimento e sobrevivência de Anadenanthera macrocarpa (Benth.) Brenan (Leguminosae), em uma área de Caatinga, Alagoinha, PE. Acta Botanica Brasilica 14: 251-261.

Silva, L.M.M., Matos, V.P., Pereira, D.D., Lima, A.A. 1995. Morfologia de frutos, sementes, e plântulas de Luetzelburgia auriculata Ducke (pau-serrote) e Pterogyne nitens Tul. (madeira-nova-do-brejo) Leguminosae. Journal of Seed Science 17: 154-159.

Souza, L.A. 2009. Sementes e plântulas: germinação, estrutura e adaptação. Ponta grossa: Toda palavra, Paraná, 1.

Voguel, E.F. 1980. Seedlings of Dicotyledons. Wageningen: Ed. Pudoc. 